\title{
The Maski Archaeological Research Project (2010-18): initial results from a multi-period interdisciplinary project on the Raichur Doab, Karnataka, India
}

\author{
Andrew M. Bauer ${ }^{1, *}$ and Peter G. Johansen ${ }^{2}$ \\ ${ }^{1}$ Department of Anthropology, Stanford University, Stanford, CA 94305, USA \\ ${ }^{2}$ Department of Anthropology, McGill University, Montreal, Quebec, H3A 2T7, Canada
}

\begin{abstract}
This article summarizes the results of five field seasons of the Maski Archaeological Research Project, an interdisciplinary project evaluating the relationships between social and environmental production throughout prehistoric and medieval periods in a $64 \mathrm{~km}^{2}$ region centred around Maski, Raichur district, Karnataka, India. We report the outcomes of intensive pedestrian survey and initial results from excavations, salvage activities and radiocarbon assessments of occupational histories. The data attest to the social and political significance of prehistoric burial practices, and medieval period settlement practices and land-use activities, highlighting how archaeological materials both belie and complement epigraphic analyses of the region.
\end{abstract}

Keywords: Archaeological survey, interdisciplinary project, medieval period, prehistory, Raichur Doab.

SINCE 2010 the Maski Archaeological Research Project (MARP) has been documenting long-term transformations in settlement organization and land-use practices (e.g. settlement, metallurgical, agro-pastoral, ritual activities) in a $64 \mathrm{~km}^{2}$ study region centred on the multicomponent site of Maski, Raichur district, Karnataka, India, through a combination of systematic surface survey, site mapping, remote sensing, surface feature and artefact attribute analyses, and, most recently, test excavations (Figure 1). Maski was previously excavated by the Archaeological Survey of India (ASI) in the 1950s and shown to have occupation attributable to Neolithic period (ca. 3000-1200 BCE) through medieval period (ca. $500-1550 \mathrm{CE})$ contexts $^{1}$. Our investigations in the region are concerned primarily with detailing how changes in settlement, agro-pastoral land use and craft production (e.g. metallurgical production) are related to novel forms of social difference and nascent inequalities, first in the prehistoric periods, and again during the early historic (300 BCE-500 CE) and medieval periods when urban set-

\footnotetext{
*For correspondence. (e-mail: ambauer@stanford.edu)
}

tlements, state polities and empires developed across South India. Indeed, Maski is situated in the western portion of the present-day Raichur district, an area that is noteworthy in historical scholarship for having been marked by social, ethnic and religious diversity, and competing imperial control during much of the medieval and early modern (ca. 1550-1850 CE) periods ${ }^{2}$. While many historians have attributed the social importance of the region to its 'fertile' agricultural land and mineral resources, and corresponding efforts to settle in the area and establish control of economic resources ${ }^{3-6}$, there has been little archaeological or ecological research on the history of land use and agricultural production in the region, leaving an assumed driver of the social and historical significance of the region fundamentally unquestioned. MARP is thus also establishing the ecological histories of the study region, reconstructing the historical role of human land use in shaping the ecologies of its inselberg landforms and the surrounding peneplain.

Here we review the outcomes of the first phase of MARP research, which included a systematic pedestrian survey, remote sensing, site mapping, and a number of test excavations and salvage activities. We also report the results of 30 radiocarbon assays that firmly establish occupation and burial practices in the region during the later Neolithic and early Iron Age (ca. 12000-300 BCE) periods, and expansive settlements and land use during the medieval period. Placing these results within the context of historical scholarship, remote sensing-based maps of landform and soil distributions, as well as archaeological survey results that include the distribution of more than 9000 low-density 'off-site' artefacts, we also provide inferences on how past spatial practices articulated with emergent forms of social distinctions.

\section{MARP research activities and methods}

Since 2010, MARP has completed five field seasons and one study season. The bulk of these activities included intensively and systematically surveying $35.2 \mathrm{~km}^{2}$ (ca. $55 \%$ ) of the $64 \mathrm{~km}^{2}$ study region at $20 \mathrm{~m}$ pedestrian 


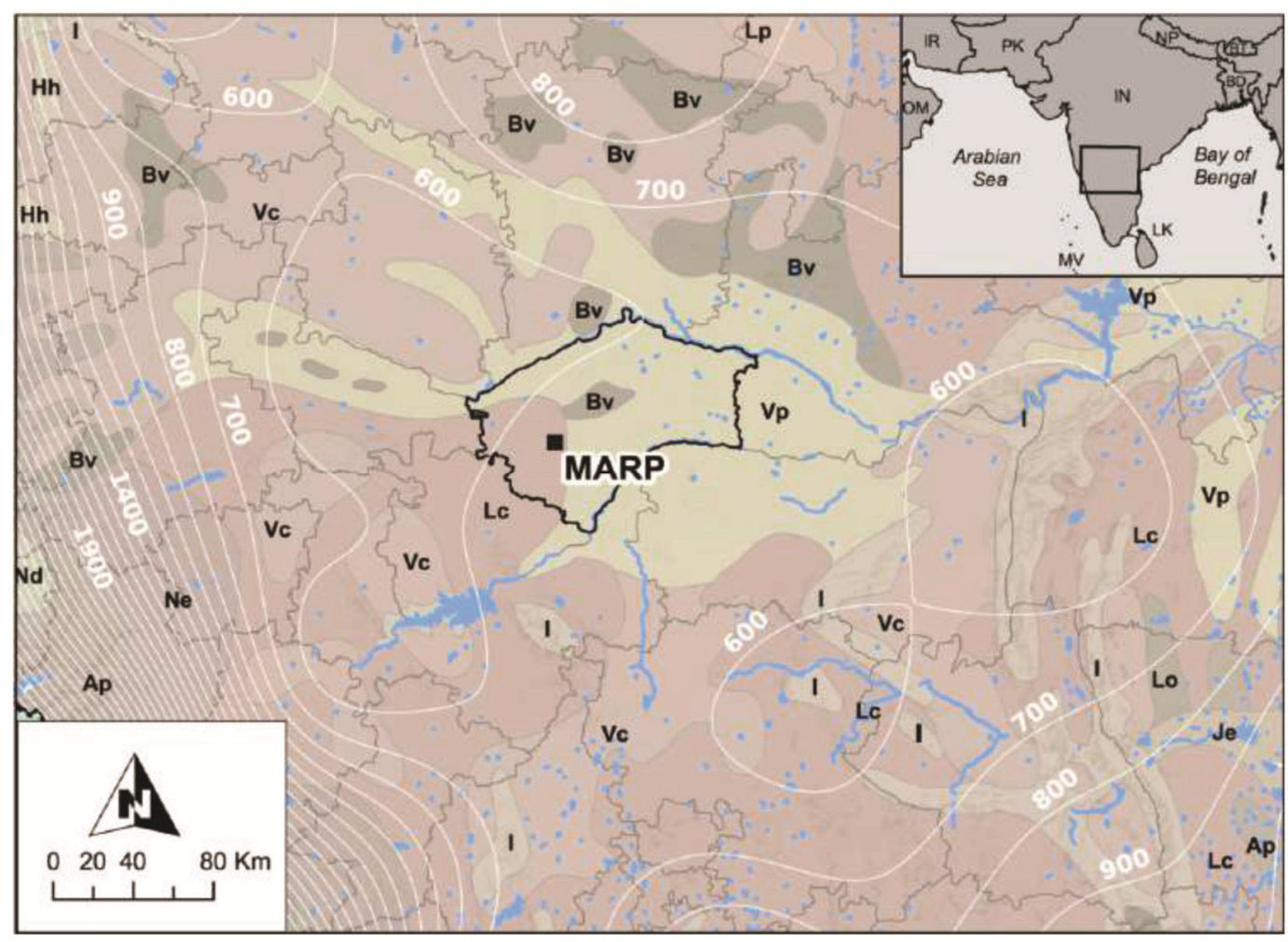

Figure 1. Location map of the Maski Archaeological Research Project (MARP) study area in Raichur district, Karnataka, India (black outline) overlain on generalized FAO soil series and $100 \mathrm{~mm}$ isohyets of the region. Isohyets were interpolated from district-level annual precipitation averages, 2014-2017, available from the Stanford Geospatial Center, USA. Ap, Plinthic Acrisols; Bv, Humic Cambisols; Hh, Haplic Phaeozems; I, Lithosols; Lc, Chromic Luvisols; Lp, Plinthic Luvisols; Je, Eutric Fluvisols; Lo, Orthic Luvisols; Nd, Dystric Nitosols; Ne, Eutric Nitosols; Vc, Chromic Vertisols; Vp, Pellic Vertisols. (District boundaries and other base data sourced from ESRI online).

spacing. Using GPS technology, the survey has recorded the location and extent of 271 archaeological sites that were identified by the presence of dense concentrations of artefacts and extant features, such as architectural elements. These sites included a variety of settlements, artefact scatters, grain-milling stations, megaliths, cemeteries, iron-working locales, gold-ore mining and processing areas, rock-art panels, occupied rock shelters, temples and shrines, and infrastructural features (e.g. wells). In addition, we recorded the locations of more than 9000 'off-site' low-density artefact scatters that are spread across the region. These low-density materials consisted typically of ceramics that were diagnostic to either the medieval period or the Iron Age and early historic period, but also occasionally included isolated distributions of iron slag and lithics. At several sites MARP has produced detailed topographic maps and has also conducted magnetic gradiometry remote sensing (e.g. MARP-155, MARP-97) to further ascertain the character of subsurface deposits. The survey encountered several archaeological contexts that had been exposed by contemporary quarrying and construction activities. In these instances, we conducted salvage section cleaning, documentation (e.g. profile drawing, photogrammetry), and sediment sampling for chemical analysis and radiocarbon assess- ment. In 2018, MARP undertook a series of test excavations to further evaluate the occupational histories and characteristics of several sites (e.g. MARP-23, MARP124, MARP-192 and MARP-266), and continued salvage documentation of occupational deposits and features exposed by modern construction. These latter activities also included excavating the partial remains of an exposed neolithic burial at MARP-79, and recording 11 other neolithic and Iron Age burials that had been disturbed by quarrying. Test excavations were carried out with $1 \times 1 \mathrm{~m}$ and $2 \times 2 \mathrm{~m}$ units, and involved $100 \%$ screening through $3 \mathrm{~mm}$ mesh for artefact recovery, and a systematic programme of soil and sediment collection for botanical flotation and additional analyses (e.g. soil chemistry, phytolith and pollen extraction, etc.). Although analysis is ongoing, several results are already noteworthy and address the research questions that frame the project.

\section{Survey results and distributional archaeology of the region}

The results point to developments in regional land-use and socio-political practices of settlement on the Deccan 
as occupation of the region increased and agriculture expanded, especially during the medieval period. Figure 2 shows an overview of documented settlements in the region according to the principal archaeological periods. Prehistoric settlement in the region is characterized by several small Neolithic period occupations and a comparatively high number of settlement sites that are attributed to the Iron Age based on the distribution of typical diagnostic surface ceramics. Most of these sites are located on the inselberg hills of the region and the Iron Age settlements are concentrated on and around the central inselberg, the Durgada Gudda, where there is also evidence for occupied rockshelters during this period and expansive panels of rock art. Excavations elsewhere in the interior Deccan suggest that during these prehistoric periods inhabitants relied on a mixed agro-pastoral economy, dry farming millets and pulses (e.g. Brachiaria ramosa, Setaria verticillata, Macrotyloma uniflorum, Vigna radiata) and herding cattle (Bos indicus), sheep (Ovis sp.) and goat (Capra sp.), the latter two of which appear to increase in the faunal remains of Iron Age deposits at some sites ${ }^{7-13}$. The MARP data suggest that smaller agropastoral communities that were dispersed across the inselberg hills aggregated at a limited number of places during the subsequent early historic period, creating fewer but larger settlement sites by the end of the first millennium $\mathrm{BCE}^{14}$.

Occupation increased significantly during the following medieval period. Survey results show an increase in the frequency of settlements, total occupied area and a broad distribution of materials across the peneplain that is inclusive of agricultural field stations. The most notable medieval period site is a walled settlement greater than 25 ha in extent. However, there is also a more extensive distribution of smaller sites and settlement areas both across the peneplain and on the central inselberg, where occupation was sometimes fortified with defensive walls. A concentration of 11 th and 12 th century stone inscriptions

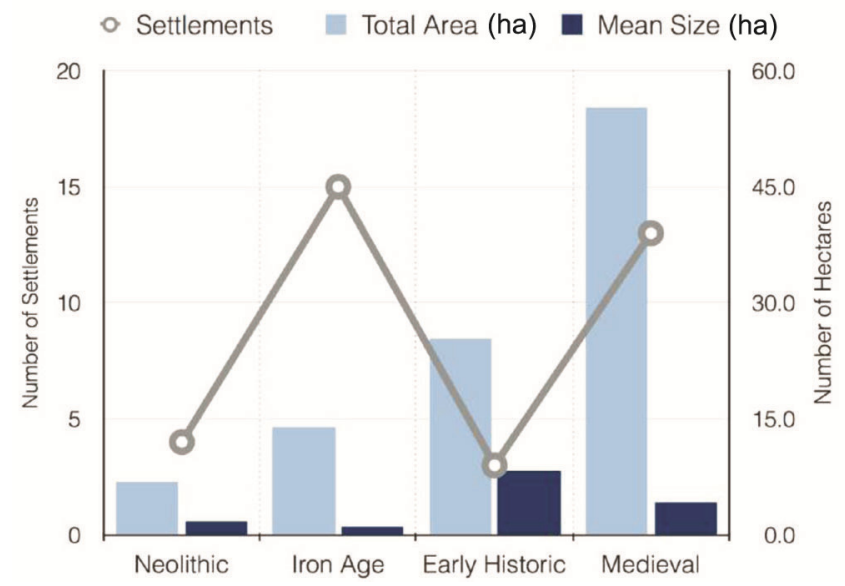

Figure 2. MARP distribution of total number of settlements, occupied area and average settlement size by principal periods. found near the largest walled site of the region suggests that the Chalukyas of Kalyani invested heavily here ${ }^{15}$. Inscriptional records also make clear that the region remained noteworthy during the latter part of the medieval period, such as during the 16th century when several Vijayanagara period land grants were also made with reference to Mosangi (as it is known in inscriptions). While it is unclear if all of the medieval period settlements recorded through survey were occupied concurrently, initial test excavations indicate that there were at least contemporaneous settlement communities on the inselberg hill and broader areas around its base during the 13th and 14 th centuries.

The recorded distribution of low-density artefacts $(<40 /$ ha $)$ also attests to settlement and agricultural expansion during the medieval period. These 'background' scatters largely correspond to the extent of past agricultural activities that can be inferred through other archaeological means, including the presence of infrastructural check-dams and sites identified as agro-pastoral field stations by discrete concentrations of artefacts, including sickle blades and storage vessels (e.g. water jars). This interpretation also has strong support from a number of scholars, who have convincingly argued that broad, low-density artefact distributions are often the result of past agro-pastoral land-use activities, and specifically manuring and fertilization practices ${ }^{16-18}$. Spatial analysis of low-density artefact distributions according to geomorphological context thus yields important information about how past inhabitants constituted agricultural spaces and cultural tasks in relation to particular assemblages of soil and other landscape features.

Statistical analyses of different artefact classes in relation to soil maps generated through multispectral remote sensing classifications of Landsat 8 data showed several significant distributional patterns ${ }^{16}$. First, Iron Age and early historic period low-density ceramics are primarily restricted to areas of the study region that are dominated by moisture-retaining, dark clay loam vertisols, i.e. regur. Second, medieval period low-density ceramics are much more broadly distributed across the study region, showing up on both dark clay loams and red sandier soils (e.g. lithosols) in more equal proportions. Third, low-density concentrations of iron slag, indicative of dispersed metalworking or smithing, rarely appear in survey blocks dominated by darker clay soils, suggesting that the dark soils were preferentially used for agricultural production. Taken together, the distributional patterns indicate spatial differences in land-use practices that produce low-density artefact scatters, such as manuring agricultural fields, between the Iron Age or early historic period and those of the medieval period (Figure 3). In short, agricultural land-use practices were extended across much of the study area in later periods, such that both dark clay-rich vertisols and the red sandy lithosols and luvisols appear to have been constituted as agricultural production spaces 


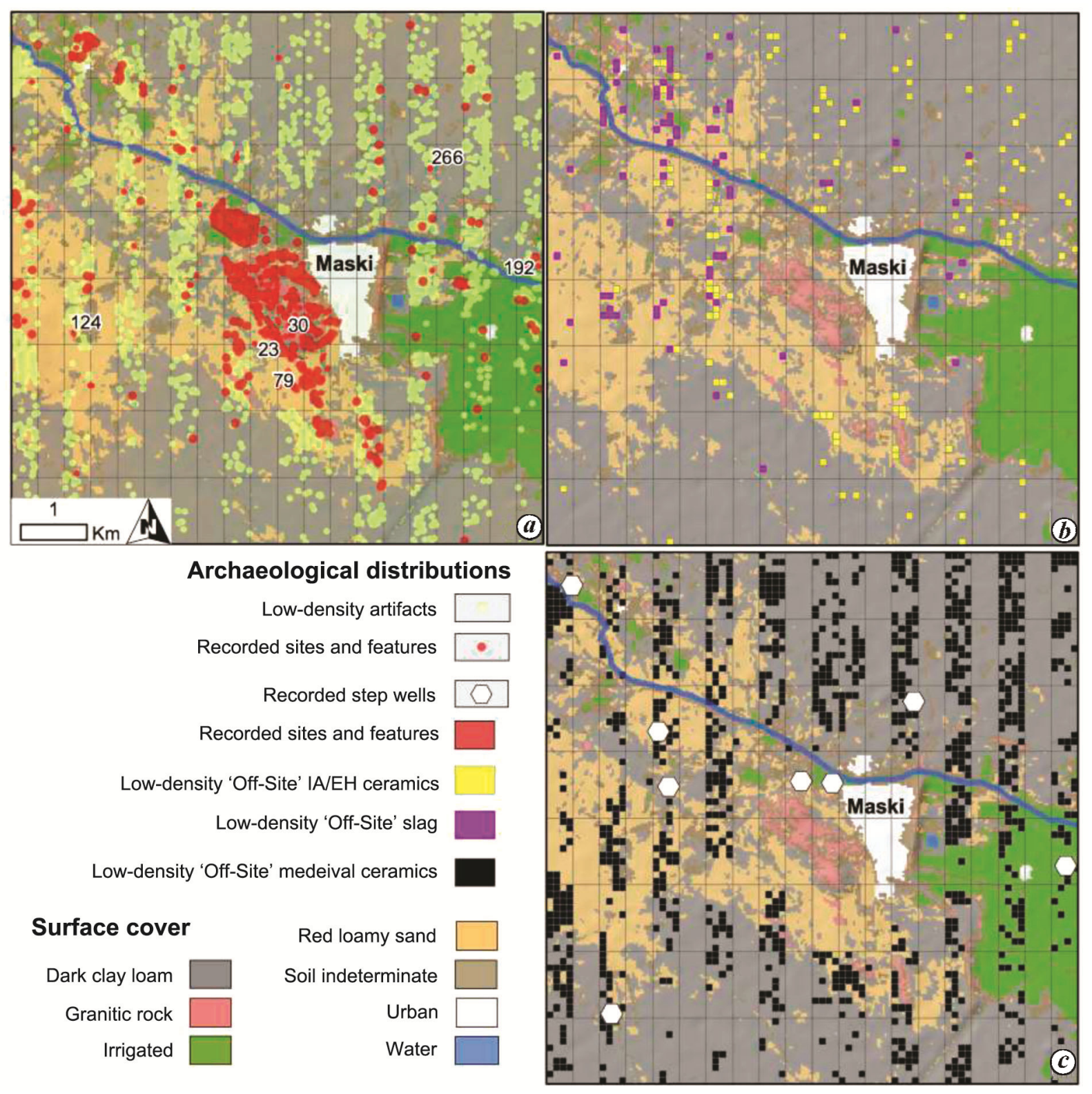

Figure 3. Distribution of (a) documented archaeological sites and 'off-site' artefacts; (b) slag and IA/EH 'off-site' distributions; (c) step wells and medieval period 'off-site' distributions.

to a degree not seen during the Iron Age and early historic periods. It is also noteworthy that the limited distribution of extant water storage and irrigation features, such as wells with water-raising mechanisms, also indicate that as agriculture expanded it did so into many contexts that were not irrigated.

\section{Medieval period settlements: test excavations and salvage activities}

To further characterize the occupational history of the medieval period sites in the region, MARP initiated a programme of test excavations in 2018. This involved placing test units at MARP-23, a 13 ha settlement site spread across the southern pediment slope of the Durgada Gudda, and several smaller sites ( $<1 \mathrm{ha})$ identified on the peneplain (e.g. MARP-124, MARP-192, MARP-266). In addition, MARP recognized an extensive profile exposure of settlement at MARP-30 that was created by recent construction activities on the Durgada Gudda. MARP recorded this profile and collected sediments for artefact and botanical analyses, and radiocarbon assessments. Taken together, these activities have allowed us to assess the chronological distribution of habitation contexts that are both on the inselberg and the surrounding plain, providing significant information on medieval period settlement practices in the region. 


\section{Settlement MARP-30}

MARP-30 is an approximately 3 ha occupational terrace recognized by extant stone-room blocks and other partially preserved architectural features (e.g. retention walls, lined pathways, etc.) on the southern portion of the Durgada Gudda (Figure 3). Its remains articulate with another 3 ha medieval period settlement on the hill (e.g. MARP-28) via a narrow pathway through a southern pass in the inselberg rock slope; whether both sites were occupied simultaneously remains to be determined, although it is probable that they were given architectural and ceramic associations. In 2014, MARP recognized a small road-cut exposure $(\sim 1.5 \mathrm{~m}$ wide and $1 \mathrm{~m}$ deep $)$ into the remains of MARP-30 that showed two distinctive occupation surfaces and a series of intervening fill deposits. Charcoal collected from the sequence yielded AMS ${ }^{14} \mathrm{C}$ assays that were conducted by the Illinois State Geological Survey (lab code ISGS) at the University of Illinois, USA. Subsequent calibrations and Bayesian analyses were preformed with OxCal v 4.2.4 (ref. 19) using the IntCal13 atmospheric calibration curve ${ }^{20}$. These results indicated that the deposits most probably resulted from occupation dating to the late 13 th century or 14 th century ${ }^{21}$. However, it is important to note that the road-cut did not expose sterile deposits at its base, and thus it is highly probable that earlier occupation is also present.

In 2018, MARP recorded a more expansive exposure ( $\sim 13 \mathrm{~m}$ long and $1.5 \mathrm{~m}$ deep) into MARP-30 associated with renewed construction and levelling activities upslope from the previously recorded exposure. The new

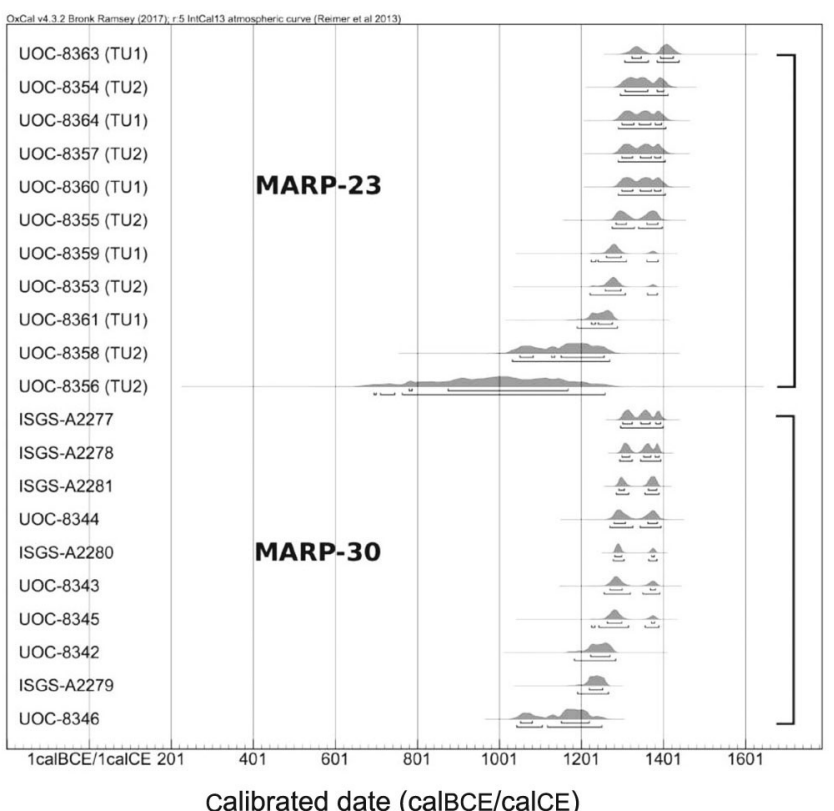

Figure 4. MARP-23 and MARP-30: probability density distributions of all calibrated radiocarbon assays. profile was drawn, photographed and sampled for artefacts, sediments and botanical remains. The exposure showed the presence of five distinctly stratified graveland cobble-packed external surfaces that were associated with the remains of core-and-veneer architectural features, some of which could be traced in profile to articulate with the partial remains of extant alignments on the present ground level. Charcoal samples were recovered from exposed surfaces and intervening fills below surfaces and submitted to the Lalonde AMS Laboratory of the University of Ottawa, Canada for radiocarbon evaluation (lab code UOC).

Five new radiocarbon assays corroborate the previous ISGS results and suggest that the settlement at MARP-30 was abandoned by the end of the 14th century, and probably earlier (Figure 4). Three of the five new assays have 'bi-modal' probability densities that calibrate to either the late 13 th century or the late 14 th century at $95 \%$ confidence because of a reversal or 'wiggle' in the IntCal13 calibration curve in the mid to late 14th century. However, the probability distributions for the other two assessments predate the late 14 th century reversal and suggest that the lowest of the exposed contexts likely date to sometime during the late 12th or 13th century. Incorporating stratigraphic information using the Bayesian 'sequence' function of OxCal v4.3.2 provides tighter constraints on the probability distributions for all the assays, suggesting that the samples date between 1204 and $1296 \mathrm{CE}$ at $68 \%$ confidence $(1 \sigma)$ as well as 1166 and

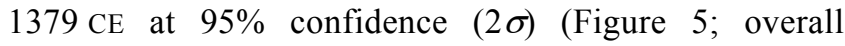
agreement index $=45.3$ ). Computing this Bayesian function without including a model outlier increased the posterior agreement index (overall agreement $=115.5$ ), but only slightly changed the modelled sample dates of the sequence, providing a $1 \sigma$ range between 1177 and $1299 \mathrm{CE}$ and a $2 \sigma$ range between 1122 and $1385 \mathrm{CE}$. Thus, the deposits most probably span the 13th century, and with a higher degree of confidence from the 12th century to the end of the 14 th century.

The beginning of occupation at MARP-30 is less certain because exposures have yet to reveal sterile deposits. However, the radiocarbon assays and models noted above suggest that the earliest materials exposed hitherto probably date to the latter part of the 12th century or early part of the 13th century. Ceramics from the MARP30 sequence are still undergoing analysis, but it can be reported that they include plain grey wares, plain black wares, slipped or polished red wares and black wares, and occasional slipped and polished black-and-red ware. Thus, as we have previously reported ${ }^{21}$, it appears certain that the medieval period ceramic assemblage at Maski, at least that which predates the 15 th century, is not restricted to the plain grey and plain black wares that are commonly reported to characterize medieval assemblages ${ }^{1}$. 


\section{Settlement MARP-23}

Test excavations at MARP-23 revealed features that suggest the site was an extensive settlement around the base of the Durgada Gudda outcrop. MARP excavated a $2 \times 2 \mathrm{~m}$ test unit (TU1) near the geomorphological divide between the inselberg rock slope and pediment slope at the northern end of the site, and an additional $1 \times 1 \mathrm{~m}$ unit (TU2) approximately $100 \mathrm{~m}$ to the southeast of the first unit on the plain. Both units reached sterile deposits and thus provide the entire range of occupation in their respective locations. Both units also evidence domestic activities and radiocarbon assays indicate that the settlement was occupied contemporaneously with portions of MARP-30 that have been exposed on the hill.

TU1 was noteworthy for exposing a portion of a stonelined circular well and several phases of associated external surfaces (Figure 6). The unit reached weathered granitic bedrock in the western portion at a depth between 85 and $90 \mathrm{~cm}$ below the ground surface. In the eastern half of the unit, within the well, excavations were carried to a depth of $260 \mathrm{~cm}$ below the surface. At that depth excavations had not reached the bottom of the deposits, but were ceased for safety concerns. The exposed portion of the

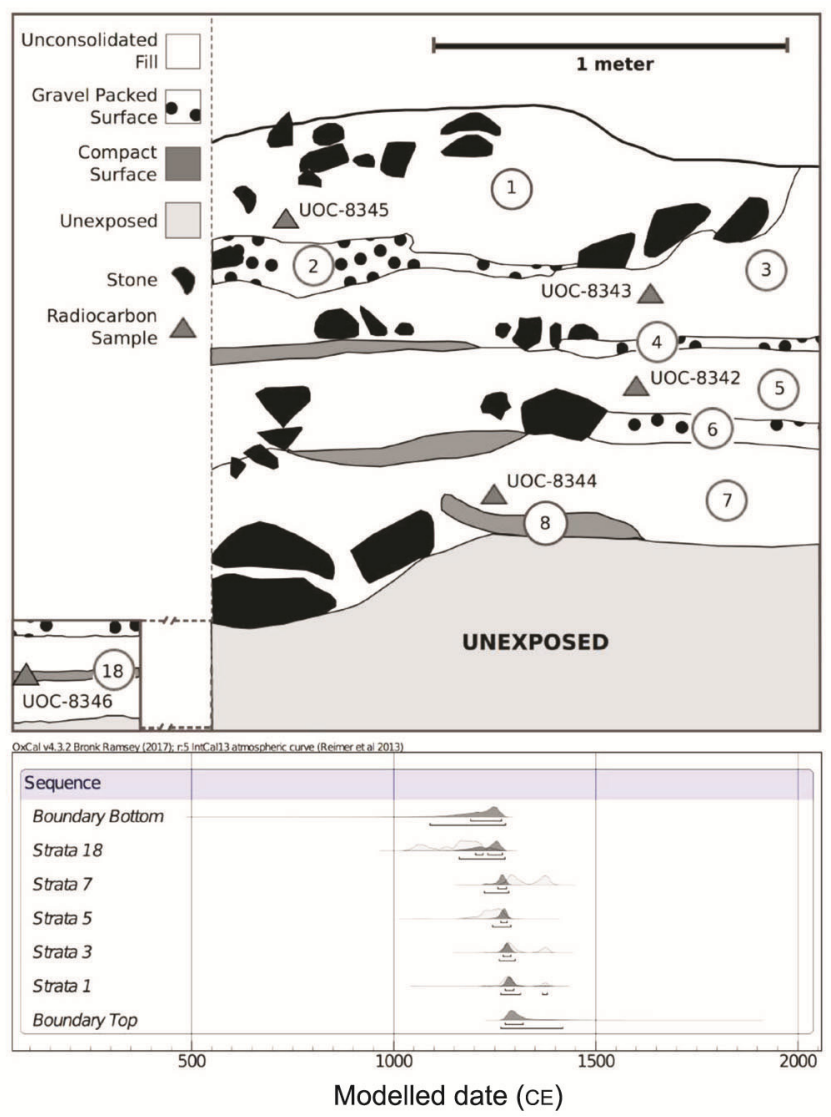

Figure 5. (Top) Stratigraphic profile of a portion of the newly exposed section in MARP-30. (Bottom) Sequence-constrained probability densities of calibrated radiocarbon assays. well showed that the feature was excavated into the underlying bedrock and preserved above by a ring of at least eight courses of tabular granitic stones, ranging from 10 to $20 \mathrm{~cm}$ in thickness. The use of the feature was associated with several distinct compact earth, gravel and cobble-packed surfaces that were evident to the north and west of the well and articulated with its mortar-lined footing.

Calibrated results of five radiocarbon assays from these stratified deposits suggest that the use of these surfaces began in the early 13th century and that the area was abandoned by end of the 14th century, and probably earlier. Unsurprisingly, the latest radiocarbon assessment (UOC-8363) obtained from the test unit resulted from a charcoal sample recovered in the well. This sample, from the lowest of the exposed strata in the feature, yielded a calibrated age between 1324 and $1425 \mathrm{CE}$ at $68 \%$ confidence $(1 \sigma)$ as well as 1306 and $1438 \mathrm{CE}$ at $95 \%$ confidence $(2 \sigma)$, implying that the well was already abandoned and beginning to silt up by at least the first half of the 15 th century (Figure 4 ).

The excavation results of TU2 provide insight into a domestic structure that was occupied simultaneously to the use of the well exposed at TU1 and the settlement at MARP-30. This suggests that medieval period occupation at Maski extended across a large area around the southern pediment slope of the Durgada Gudda and concurrently on the hill between the 13th and 14th centuries. The $1 \times 1 \mathrm{~m}$ exposure of TU2 revealed the corner of a domestic room, evident by the remains of a compact mud wall that arched from the northeastern corner of the unit to its southwestern corner. In the area to the south and east of the extant walls, excavations revealed an approximately $60 \mathrm{~cm}$ thick deposit of plaster surfaces. The surfaces were

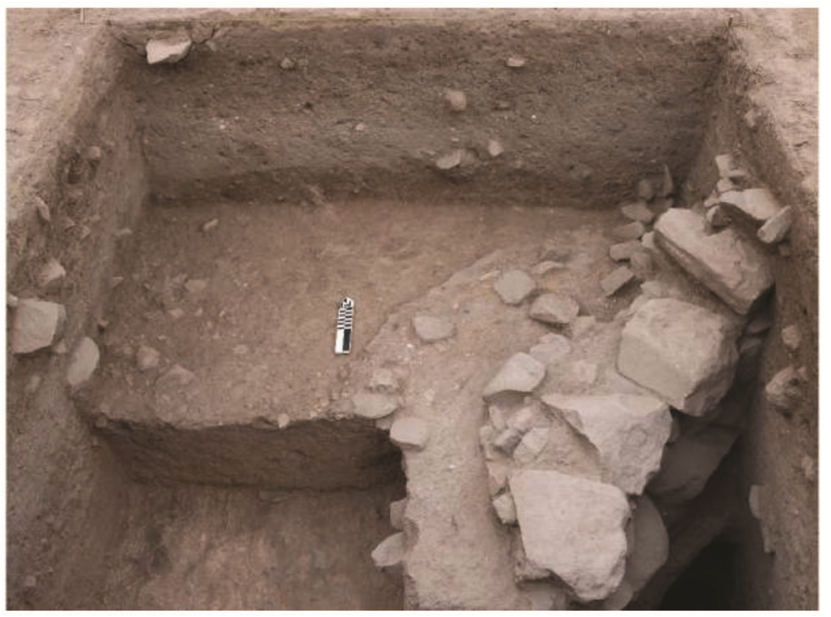

Figure 6. TU1 MARP-23: upper course of stone-lined well in the southeastern portion of the unit and mortar-line cobble base in association with cobble- and sherd-packed surface to the north and west. Southwestern quadrant of the unit was excavated into underlying sterile weathered granitic regolith to expose internal stratigraphy of well footing. 


\section{RESEARCH ACCOUNT}

better preserved at lower depths, where a sequence of alternating bands of silt-rich, light grey plaster was periodically separated by thin layers of packed, greyishbrown, sandy loam (Figure 7), suggestive of routine replastering of the floor and walls. Artefacts associated with these floor deposits included both open and restricted mouth ceramic forms, such as storage jars and shallow serving vessels (i.e. plates). The room block was constructed on a thin platform $(9-14 \mathrm{~cm})$ of rammed mud, under which a sterile stratum of weathered regolith was reached at approximately $100 \mathrm{~cm}$ below the present ground surface. Radiocarbon assays from the floor sequence in TU2 indicate that the structure was occupied sometime during the 13 th and 14th centuries, although two radiocarbon evaluations with exceptionally large errors (UOC-8356, UOC-8358) suggest that it could have been established more than a century earlier (Figure 4).

\section{Peneplain sites MARP-124, MARP-192, MARP-266}

In addition to documenting the occupational history of medieval period settlements in the vicinity of the Durgada Gudda, MARP also excavated $1 \times 1 \mathrm{~m}$ test units at multiple sites (MARP-124, MARP-192, MARP-266) that were identified as possible medieval or early modern period 'field stations' or 'farmsteads' during the survey to further evaluate the occupation and extension of land use on the peneplain. As expected, all of these sites were shallow. Excavations reached underlying sterile strata between 20 and $40 \mathrm{~cm}$ below the surface at MARP124 and MARP-266, and $50 \mathrm{~cm}$ below the surface at MARP-192. It is important to note that all of these sites are actively under modern cultivation, and thus their

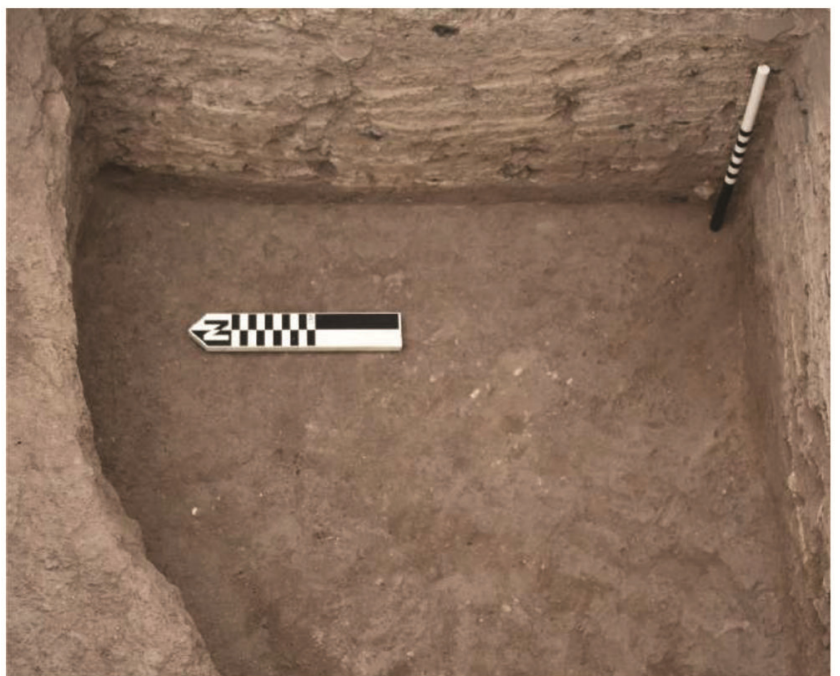

Figure 7. TU2 MARP-23: upper portion of mud platform upon which repeated plaster surfaces were constructed (shown in the eastern and southern profile) to articulate with the mud wall base evident toward the northern bulk. insubstantial depths indicate that most of the contexts were highly disturbed by contemporary land use. Yet archaeological features, such as a compact activity surface with associated artefacts and ash lens were noted under the plow zone at MARP-192, confirming primary archaeological contexts in places; a sediment sample submitted for radiocarbon assessment from this test unit, however, failed to yield a result. All deposits at MARP124 and MARP-266 were highly contaminated by current land use; a single radiocarbon assay from the latter site yielded a calibrated result of $1515-1935 \mathrm{CE}$ at $95 \%$ confidence with the greatest probability of dating to the 17 th century (1617-1684 CE) and only a slight probability of postdating $1805 \mathrm{CE}$, despite the relative 'flatness' of the calibration curve from the mid-17th century onward (Figure 8). Although additional sites and locales warrant testing, the initial excavations of these smaller sites provided tentative corroboration of the presence of dispersed medieval or early modern period deposits on the plain beyond the low-density 'background' distributions recorded during survey.

\section{Neolithic and Iron Age Burial practices}

MARP-79 is a 2 ha cemetery site located on the pediment slope west of an inselberg, south of the Durgada Gudda. It was identified in 2012 during systematic survey through a series of quarry pits that had damaged the deposits. Burials containing human skeletal remains, slipped, slipped and polished ceramics, copper and iron objects, and ground stone lithics were observed scattered across open quarry pits and in exposed sections. Documentation of partially exposed features began in 2012 and continued in 2014, in an effort to salvage information about these rapidly disappearing burials. This included photographs and section drawings and the collection of artefacts, human remains and charcoal samples for future

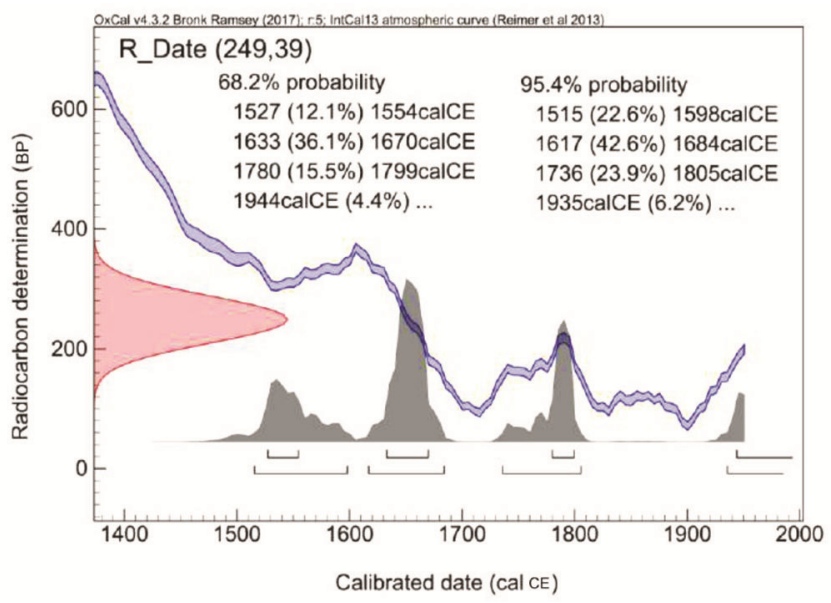

Figure 8. MARP-266: probability density distributions for calibrated age of sample. 


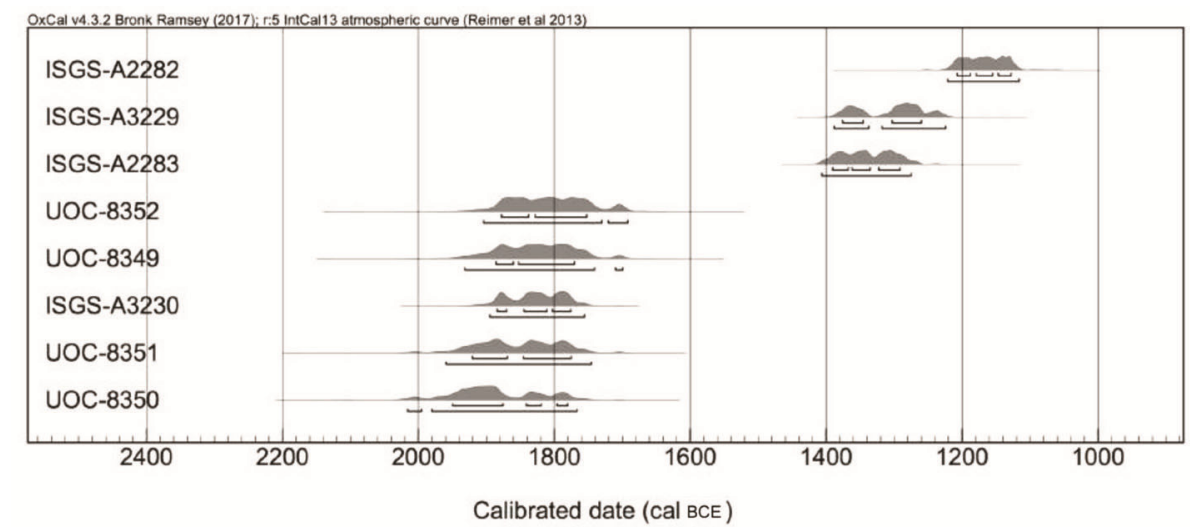

Figure 9. MARP-79: probability density distributions of all calibrated radiocarbon assays from the site.

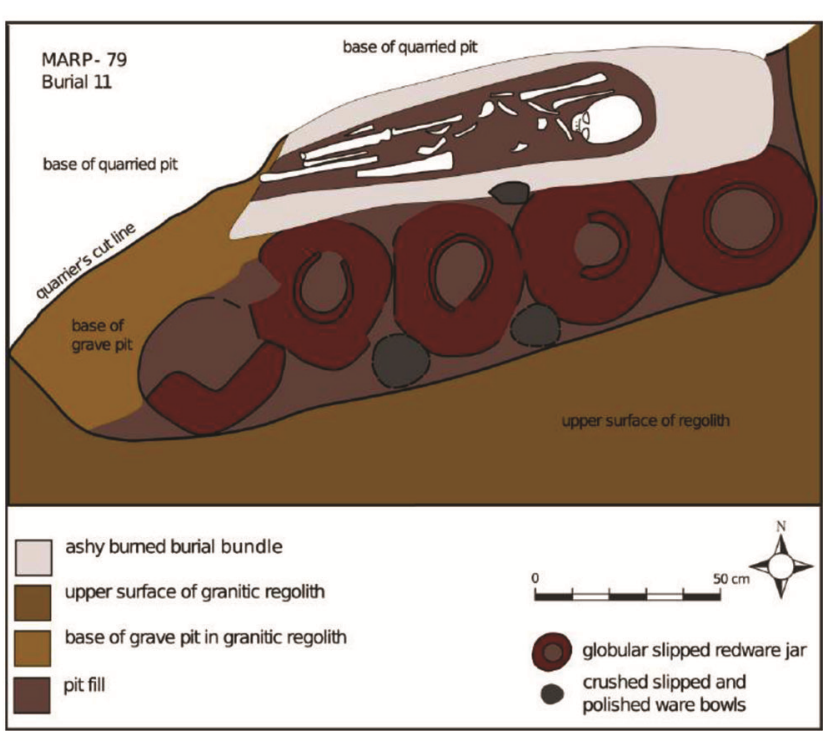

Figure 10. MARP-79: plan of Burial 11.

analysis. Nine burials were documented during 2012 and 2014, and charcoal samples were collected from three (Burials 1, 6 and 7) that yielded AMS ${ }^{14} \mathrm{C}$ assays conducted by ISGS ${ }^{14,21}$. The results dated two of the burials to between the 15 th and 12 th centuries $\mathrm{BCE}$ while the third dated to between the 19th and 18th centuries BCE, demonstrating that this cemetery was in use from at least the late neolithic period to the early part of the Iron Age $\left(\right.$ Figure 9) ${ }^{21}$.

In 2018, 11 new burials were identified, one of which (Burial 11) was selected for excavation because it was still largely intact (in spite of having been quarried into) and under immanent threat of complete destruction. Excavations exposed an overlying soil matrix above a $220 \mathrm{~cm}$ long grave pit cut approximately $70 \mathrm{~cm}$ deep into weathered granitic regolith to a level base. The base of the grave contained a 'bundle' of light grey ashy material that was wrapped around a single extended human skeleton. The skeletal remains were approximately articulated, yet friable and fragmentary, suggesting possible disincarnation followed by 'rearticulating' the remains prior to encasement in an organic material, which then appears to have been burned in situ (Figure 10). South of the body, five globular, slipped red ware jars were arranged in a row with four carinated bowls placed above or below at their intersection and a large elongated bowl capped the easternmost jar. Charcoal was recovered from the bundle, fill and contents of the jars.

Charcoal samples were also collected from several of the newly documented burials and from one partially destroyed sarcophagus burial identified in 2014 (Burial 8). Three samples from Burial 11 and one sample from the burial pit immediately below the terracotta sarcophagus of Burial 8 were submitted for radiocarbon evaluation (Figure 9, UOC codes). Combining the three dates from Burial 11 gives a $2 \sigma$ calibration between 1917 and $1771 \mathrm{BCE}$ (Figure 11, agreement index =99.6). The results of these new dates complement and corroborate previous ISGS results, and suggest that the cemetery was active from at least the 20th to 12th centuries BCE, confirming the perduring use of this place for mortuary practices.

\section{Discussion: toward a social and historical archaeology at Maski}

The MARP results reviewed above add several important substantive and methodological contributions to interpreting social and environmental production on the Raichur Doab. It is significant that settlement communities differentiated by both architectural materials and spatial locations relative to the inselberg hill were occupied concurrently during the medieval period at Maski. For instance, architectural elements and the remains of extant defensive walls and domestic structures at MARP-30 and MARP-28 are composed of granitic stones, some of which are quarried and shaped boulder-sized blocks. In contrast, the domestic structure revealed at MARP-23 


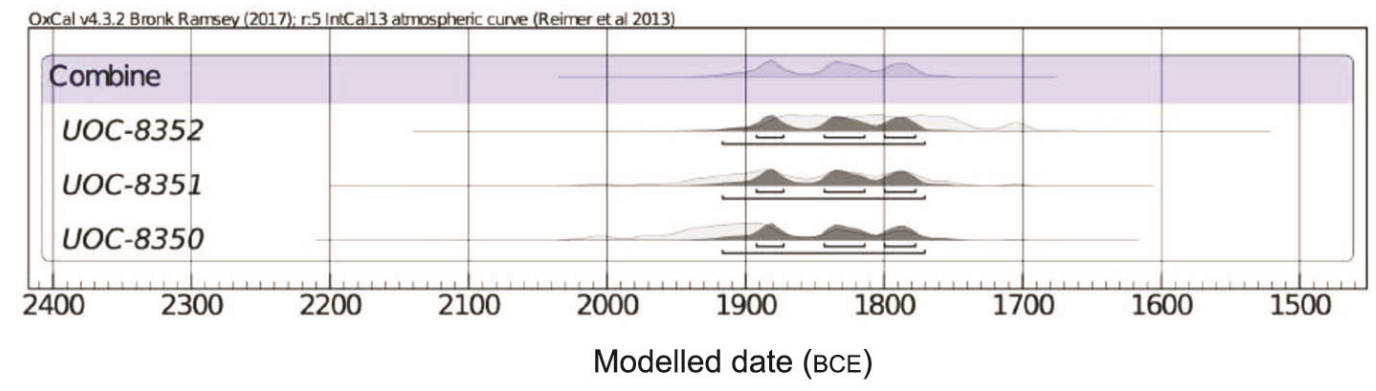

Figure 11. MARP-79: combined probability density distributions for calibrated ages of Burial 11 .

was built of packed mud. Moreover, survey of MARP-23 suggests that there are comparatively few stone structures across the expansive settlement. Thus, MARP-30 and MARP-23 provide evidence for noteworthy differences in construction practices and labour regimes in creating these distinct settlement landscapes.

The significance of these spatial distinctions between settlement zones on and off the hill is further highlighted by well-attested martial conflict in the region during the medieval period. Scrutiny of epigraphic records of the Chalukyas of Kalyani and the Chola empires suggests that these rival dynasties met in battle on the Raichur Doab at least six times between 1005 and $1068 \mathrm{CE}$ alone, including an encounter at Maski in $1021 \mathrm{CE}$ (ref. 22). During at least a portion of the period in which MARP-23 and MARP-30 were probably occupied in the 13th century, the area was also the object of competing sovereign claims by Yadava feudatories who were based at Mudgal, only $20 \mathrm{~km}$ to the west of Maski, and feudatories of the Kakatiyas, who would build the fort at nearby Raichur to the east of Maski in $1294 \mathrm{CE}$, after several successful battles in the area ${ }^{15}$. Moreover, between 1362 and $1565 \mathrm{CE}$ the armies of Vijayanagara and various Deccan sultanates would wage at least 14 campaigns against each other in the region ${ }^{3,23}$. When one also includes historical evidence for smaller skirmishes and livestock raids, the frequency of violent confrontation on the Raichur Doab during the medieval period appears to be relatively high. Inhabitants of Maski would almost certainly have been cognizant of potential or impending conflict in the vicinity, and thus, the settlement distinctions among residents who lived and laboured in earthen structures around the base of the hill and those who resided behind defensible stone walls on the hilltop terraces were probably highly meaningful to community inhabitants. Indeed, it appears that both MARP-30 and MARP-23 were abandoned around the time that Raichur fort was constructed and subsequent conflict developed in the 14th century, suggesting that strife or imperial relocation strategies may have had an important impact on settlement practices at Maski.

This recognition leads us to several important points about the relationships between archaeological data and the historiography of the Deccan, and the Raichur Doab specifically. The archaeological evidence for extensive occupation at Maski during the 13th and 14th centuries belies epigraphic evidence for the chronological distribution of occupation at the site. Medieval period dated inscriptions found in the vicinity of Maski date almost exclusively to one of two periods: an early period between the 11 th and 12 th centuries when the Chalukyas invested heavily in the place, and a later period during the first half of the 16th century associated with Vijayanagara claims to the region. Thus, it is evident from MARP-23 and MARP-30 that there was extensive occupation at Maski during a period when the published epigraphic record for activity there is effectively silent. Indeed, if the other associated medieval period settlements recorded by MARP (e.g. MARP-28, MARP-88 and MARP-102) were also simultaneously occupied during the 13th and 14th centuries, then that period would represent the apogee of occupation in the project area, despite an apparent dearth of activities (e.g. temple patronage, donative practices, etc.) associated with the primary historical sources of the period (i.e. commissioned inscriptions). Thus, the common historical practice of using monumental evidence and inscriptional sources to infer the distribution of significant places and occupational histories during the medieval period should always be questioned for its biases, and what they both illuminate and obscure.

In this regard, the MARP 'off-site' survey data partially corroborate historical scholarship that has suggested that the Raichur Doab was important for agricultural production during the medieval period, while also complementing this assessment in critical ways. As illustrated by the remote sensing and spatial analyses around Maski, it is important to underscore that there is significant soil variability on the Raichur Doab, and it is evident that agricultural expansion did not occur on equally waterretentive, irrigated or 'fertile' soils. In fact, the distribution of step wells and irrigation features documented by MARP demonstrate that much of the area cultivated during the medieval and early modern periods was not irrigated with infrastructure. In this semiarid context, the distinction between moisture-retentive, clay-rich soils and less-retentive, sandy, red soils was probably highly meaningful to inhabitants of the region for the production of 
culturally valued cultigens. In fact, medieval donative inscriptions from the vicinity of Maski, and across the Raichur Doab more generally, often imply that 'black' soil was favoured over 'red' for some important cultigens, frequently showing up as a marked land donation to temples. Thus, archaeological evidence for the extension of agriculture to unirrigated, red sandier soils around Maski goes beyond merely substantiating medieval period agricultural expansion on the Raichur Doab. The inscriptional records and archaeological data collectively suggest that differences in the social value and uses of particular water and soil assemblages contributed to emergent forms of inequality as some inhabitants practised agriculture in social and environmental contexts that were potentially marginalizing. In the semiarid context of the interior Deccan, inhabitants would have had unequal capabilities to generate culturally valued crops, such as cotton and rice, that had well attested relationships to different economic and ritual practices.

The 'off-site' survey data also point to important patterns in prehistoric land-use practices with implications for understanding socially important changes in agricultural production. The earliest evidence for agricultural field stations and field manuring on the peneplain date to the Iron Age or early historic period when low-density sherd scatters and small, but at times, dense artefact scatters were located largely on the moisture-retentive, clay-rich soils. This pattern is contrasted by that of the preceding Neolithic period when off-site sherd deposits were negligible on the peneplain and by the pattern discussed above for the medieval period. Neolithic agricultural practices in northern Karnataka began with domestication of a localized suite of drought-resistant pulses and millets that can grow in the red sandy soils and dark vertisols, followed by the incorporation of non-local cereals (e.g. barley, wheat) sometime between 2000 and $1800 \mathrm{BCE}$ and then additional pulses such as hyacinth bean (ca. 1600 BCE) and pigeon pea ${ }^{8,24,25}$. The cultivation of some of these new crops (e.g. wheat and barley) may have involved an additional growing season, attendant watermanagement strategies, or new scheduled uses of moisture-retentive, clay-rich soils in the years of heavy rainfall, conditions which may have called for significant adjustments to seasonal labour requirements and social relations of agricultural production ${ }^{7,25-27}$. Moreover, these new crops would have generated important new additions to local cuisine, something supported by changes in regional ceramics that include a diversification of new serving vessels by at least 1400-1200 BCE (refs 7, 13, 24, 26-28).

Early radiocarbon assays from the cemetery at MARP79 date to the 20 th -18 th centuries BCE, providing some of the earliest evidence for contemporaneous distinctions in mortuary practices (i.e. sarcophagus burial, fabricwrapped cremation, simple jar burial) in the region. These dates also correspond with radiocarbon assays from macro-botanical remains recovered from other sites in northern Karnataka that document the incorporation of new crops into regional agricultural practices. Changing social relationships involving new crop sowing and harvesting schedules, together with novel kinds of cuisine developed from non-local crops, may have created the conditions for new approaches to social differentiation involving the organization of agricultural labour and food consumption practices. Moreover, Burial 11 contained four carinated serving vessels with slipped and polished surface treatments that resemble vessel forms from the succeeding Iron Age. These vessels are among the earliest of their kind yet recorded and may suggest the instantiation of Late Neolithic social distinctions through mortuary practices that occasioned the consumption of differentially valued cultigens. These Late Neolithic mortuary contexts might be early examples of nascent social distinctions that developed in part from shifting production emphases and consumption differences, changes antecedent to the monumental (megalithic) mortuary practices and social inequalities of the Iron $\mathrm{Age}^{7,21}$.

\section{Conclusion}

Five MARP field seasons have produced valuable new information about the long-term histories of regional settlement and land-use practices, and the development of social distinctions and inequalities during multiple archaeological periods. Intensive survey and remote sensing results identified previously undocumented temporally dynamic patterns of association between archaeological sites and 'off-site' artefact distributions with landscape features and geomorphological contexts that suggest strategic reorderings of settlement, agricultural production, and assemblages of people, culturally valued soils and cultigens. Moreover, excavations and salvage work have elucidated significant patterns in medieval settlement history that demonstrate occupation of the region during a crucial period of relative silence in the inscriptional records, when the location, labour and building materials of residential contexts appear to be socially differentiated around Maski. MARP is also documenting evidence for very early instantiations of social distinctions through mortuary practices that appear to emerge at a time during the Late Neolithic period when non-local crops were being incorporated into South Indian agropastoral activities. Future field seasons will continue to pursue methodologically innovative, multidisciplinary approaches to investigating the articulations between developing social relationships and historical shifts in production, consumption and spatial practices.

1. Thapar, B. K., Maski 1954: a chalcolithic site of the southern Deccan. Ancient India, 1957, 13, 4-142.

2. Asher, C. B. and Talbot, C., India Before Europe, Cambridge University Press, Cambridge, UK, 2006, pp. 163-166. 


\section{RESEARCH ACCOUNT}

3. Eaton, R. M. and Wagoner, P. B., Power, Memory, Architecture, Oxford University Press, Oxford, UK, 2014, p. 242.

4. Derrett, J. D. M., The Hoysalas, Oxford University Press, London, UK, 1957, p. 59.

5. Eaton, R. M., A Social History of the Deccan, 1300-1761: Eight Indian Lives, Cambridge University Press, Cambridge, UK, 2005, pp. 88-89.

6. Philon, H., Gulbarga, Bidar, Bijapur, Jaico, London, UK, 2017, pp. 13-15.

7. Bauer, A. M., Johansen, P. G. and Bauer, R. L., Toward a political ecology in early South India: preliminary considerations of the sociopolitics of land and animal use in the southern Deccan, Neolithic through early historic periods. Asian Perspect., 2007, 46, 138.

8. Fuller, D. Q., Indus and non-Indus agricultural traditions: local development and crop adoptions on the Indian peninsula. In Indus Ethnobiology (eds Weber, S. and Belcher, W.), Lexington Books, Lanham, Maryland, USA, 2003, pp. 343-396.

9. Korisettar, R., Venkatasubbaiah, P. C. and Fuller, D. Q., Brahmagiri and beyond: the archaeology of the southern Neolithic. In Indian Archaeology in Retrospect: Prehistory Archaeology of South Asia (eds Settar, S. and Korisettar, R.), Manohar, New Delhi, 2001, pp. 151-237.

10. Paddayya, K., The problem of ashmounds of southern Deccan in the light of Budihal excavations, Karnataka. Bull. Deccan Coll. Post-Grad. Inst., 2001, 60-61, 189-225.

11. Sastri, T. V. G., Kasturi Bai, M. and Prasada Rao, V. J., Veerapuram, Birla Archaeological and Cultural Research Institute, Hyderabad, 1984

12. Thomas, P. K., Deshpande-Mukherje, A. and Shobha, V., Faunal assemblages from Kanenur, Kaveripura and Kannifere: Iron Age/early historic sites in Karnataka. Man Environ., 2006, 31, 7580 .

13. Morrison, K. D., Reddy, S. N. and Kashyap, A., Agrarian transitions in Iron Age southern India: social and environmental implications. In South Asian Archaeology and Art 2012 (eds Lefèvre, V., Didier, A. and Mutin, B.), Brepols, Turnhout, Belgium, 2016, pp. 185-196.

14. Johansen, P. G. and Bauer, A. M., Beyond culture history at Maski: land use, settlement and social differences in neolithic through medieval South India. Archaeol. Res. Asia, 2015, 1, 6-16.

15. Patil, C. S. and Patil, V. C., Inscriptions of Karnataka Vol. IV: Inscriptions of Raichur District, Directorate of Archaeology and Museums, Mysore, 1998.

16. Bauer, A. M., Remote sensing soils and social geographies of difference: the landscape archaeology of regur from Iron Age through medieval period northern Karnataka, Southern India. $J$. Field Archaeol., 2018, 43, 31-43.

17. Bintliff, J. and Snodgrass, A., Off-site pottery distributions: a regional and interregional perspective. Curr. Anthropol., 1988, 29, 506-513.

18. Wilkinson, T. J., Extensive sherd scatters and land-use intensity: some recent results. J. Field Archaeol., 1989, 16, 31-46.

19. Bronk Ramsey, C. and Lee, S., Recent and planned developments of the program OxCal. Radiocarbon, 2013, 55, 720-730.
20. Reimer, P. J. et al., IntCal13 and Marine13 radiocarbon age calibration curves 0-50,000 years cal BP. Radiocarbon, 2013, 55, 1869-1887.

21. Bauer, A. M. and Johansen, P. G., Prehistoric mortuary practices and the constitution of social relationships: implications of the first radiocarbon dates from Maski on the occupational history of a South Indian 'type site'. Radiocarbon, 2015, 57, 795-806.

22. Murari, K., The Calukyas of Kalyani, Concept Publishing House, Delhi, 1976, pp. 57-60.

23. Kadiri, A. A., Epigraphia Indica: Arabic \& Persian Supplement, Archaeological Survey of India, Government of India Press, 1962, pp. 53-57.

24. Fuller, D. Q., Boivin, N. and Korisettar, R., Dating the neolithic of South India: new radiometric evidence for key economic, social and ritual transformations. Antiquity, 2007, 81, 755-778.

25. Roberts, P. et al., Local diversity in settlement, demography and subsistence across the southern Indian Neolithic-Iron Age transition: site growth and abandonment at Sanganakallu-Kupgal. Archaeol. Anthropol. Sci., 2016, 8, 575-599.

26. Johansen, P. G., On the cusp of social change: iron working and cattle keeping at Bukkasagara at the onset of the South Indian Iron Age in northern Karnataka. Archaeol. Res. Asia, 2019; doi.org/10. 1016/j.ara.2019.02.003

27. Fuller, D. Q., Ceramics, seeds and culinary change in prehistoric India. Antiquity, 2005, 79, 761-777.

28. Sinopoli, C. M., Ceramic change and ceramic use in late prehistoric South India: the evidence from Kadebakele (Koppal District, Karnataka). In South Asian Archaeology and Art 2012 (eds Lefèvre, V., Didier, A. and Mutin, B.), Brepols, Turnhout, Belgium, 2016, pp. 291-304.

ACKNOWLEDGEMENTS. The Maski Archaeological Research Project is a collaboration between the Karnataka Department of Archaeology, Museums and Heritage (KDAMH), and the present authors. We thank the Archaeological Survey of India for permission to conduct research at Maski (F.1/8/2009-EE). We also thank the National Science Foundation of the United States, the Fulbright-Nehru program of the United States-India Educational Foundation, the Social Sciences and Humanities Research Council of Canada, the University of Illinois, DePauw University and Stanford University for financial support; the American Institute of Indian Studies for assistance and continuous support, and particularly Dr Pradeep Mehendiratta, Purnima Mehta and Dr Vandana Sinha; friends, colleagues and project co-directors at KDAMH, including T. S. Gangadhar, Dr R. Gopal, Dr Gavisiddaiah and N. L. Gowda; and finally Andrew Suarez and Charles Roseman (University of Illinois) for providing laboratory space to process materials.

Received 3 April 2019; accepted 8 May 2019

doi: $10.18520 / \mathrm{cs} / \mathrm{v} 117 / \mathrm{i} 1 / 46-56$ 